\title{
FAGUAYTERRITORIO
}

\section{Municipalización y modernización del servicio de abastecimiento de agua en España: el caso de Málaga (1860-1930)}

\author{
Municipalization and Modernization of Water Supply Service \\ in Spain: The Case of Malaga (1860-1930)
}

Víctor M. Heredia-Flores

Universidad de Málaga. Málaga, España. vmheredia@uma.es

\begin{abstract}
Resumen - El estudio de casos locales permite profundizar en el conocimiento de la evolución de los modelos de organización y gestión del servicio de abastecimiento de agua en las ciudades españolas entre la segunda mitad del siglo XIX y las primeras décadas del XX. La incapacidad técnica y financiera de las administraciones locales para acometer la modernización de los sistemas de suministro promovió el recurso a las concesiones a particulares como solución más habitual en las grandes poblaciones como Málaga. En esta ciudad el servicio fue explotado desde 1876 por varias empresas privadas que desarrollaron un modelo de negocio especulativo, caracterizado por la carencia de inversiones y el progresivo deterioro del servicio. Finalmente, el Ayuntamiento rescató la concesión en 1913 y realizó un ambicioso proyecto de renovación del servicio entre 1923 y 1929. El cambio de modelo de gestión se tradujo en una modernización parcial del sistema y en la superación de las actividades especulativas en torno al suministro, pero fue insuficiente para satisfacer las demandas sociales y urbanas de una ciudad en crecimiento.

Abstract - The study of local cases allows to penetrate into the knowledge of the evolution of the models of organization and management of water supply service in the Spanish cities between the second half of the 19th century and the first decades of the 20th. The technical and financial inability of local governments to undertake the modernization of network systems promoted use of concessions to the private sector as usual solution in large cities like Malaga. In this city the improvement of the supply in the period 1870-1930 went through two phases. In the first, the lack of funds to modernize the service, that the local bourgeoisie needed to develop its residential and industrial projects, made the water be brought from Torremolinos, which was exploited from 1876 by several private companies - capital initially French and British, later Spanish, which developed a model of speculative business, characterized by lack of investment and the progressive deterioration of service. The new situation of municipal politics, with a majority of Republicans and Socialists, and rivalries within the Conservative Party provided a change in attitude towards this problem. Finally, the Malaga City Council began the process of rescuing the concession in 1913, which was one of the first municipalities that did it in Spain and embarked on an ambitious project to renovate the service between 1923 and 1929. The change of management model implied a real system upgrade -though incomplete, since the distribution network was not realized, and overcoming speculative activities around the supply, but it was insufficient to satisfy the social and urban demands of a growing city. The municipalization raised expectations of improvement which were only partly met, because the problem of water supply remained in the following decades until the end of the 20th century.
\end{abstract}

Palabras clave: Servicios urbanos, abastecimiento de agua, municipalización, modernización, Málaga Keywords: Urban services, water supply, municipalization, modernization, Malaga

Información Artículo: Recibido: 29 septiembre 2012 Revisado: 29 noviembre $2012 \quad$ Aceptado: 1 marzo 2013

Códigos JEL: N73, N74

(c) Universidad de Jaén / Seminario Permanente Agua, Territorio y Medio Ambiente (CSIC) 